\title{
Lack of Sarcocystis neurona Antibody Response in Virginia Opossums (Didelphis virginiana) Fed Sarcocystis neurona-Infected Muscle Tissue
}

\author{
Author(s): M. A. Cheadle, D. S. Lindsay , E. C. Greiner \\ Source: Journal of Parasitology, 92(3):652-654. 2006. \\ Published By: American Society of Parasitologists \\ DOI: http://dx.doi.org/10.1645/GE-788R.1 \\ URL: http://www.bioone.org/doi/full/10.1645/GE-788R.1
}

BioOne (www.bioone.org) is a nonprofit, online aggregation of core research in the biological, ecological, and environmental sciences. BioOne provides a sustainable online platform for over 170 journals and books published by nonprofit societies, associations, museums, institutions, and presses.

Your use of this PDF, the BioOne Web site, and all posted and associated content indicates your acceptance of BioOne's Terms of Use, available at www.bioone.org/page/terms_of_use.

Usage of BioOne content is strictly limited to personal, educational, and non-commercial use. Commercial inquiries or rights and permissions requests should be directed to the individual publisher as copyright holder. 


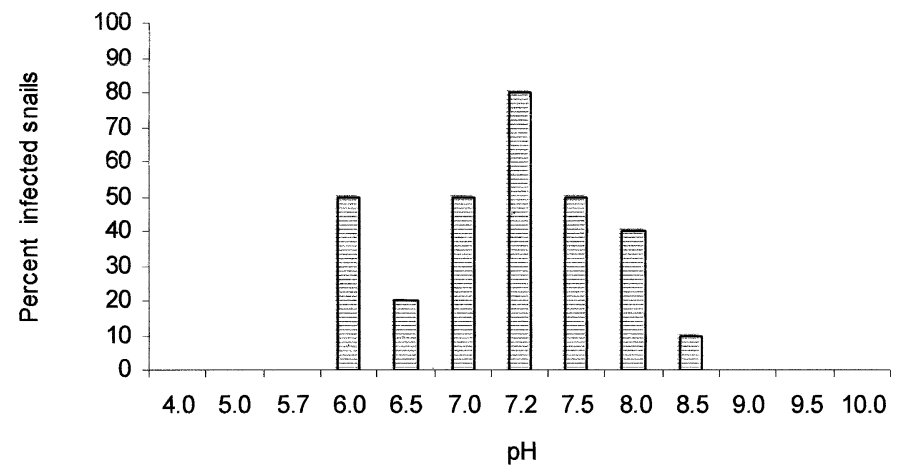

FIGURE 2. Infection of L. (Fossaria) humilis with F. hepatica at different pHs. Every $24 \mathrm{hr}$, dead snails were dissected and examined to determine infection by $F$. hepatica. The experiment was stopped at day 18 , when the remaining molluscs were examined.

2005). Humidity and temperature have been observed to correlate with peaks of infection in snails. Changing $\mathrm{pH}$ of a water body also could modify the infectivity of this parasite for its intermediate host, but this hypothesis has not yet been addressed under natural conditions.

\section{Literature Cited}

Abrous, I., D. Rondelaud, And G. Dreyfuss. 2001. The stress of Lymnaea truncatula just before miracidial exposure with Fasciola hepatica increased the prevalence of infection. Experimental Parasitology 99: 49-51.

BORAY, J. C. 1969. Experimental fascioliasis in Australia. Advances in Parasitology 7: 95-169.

Boyce, W. M., AND C. H. Courtney. 1990. Seasonal transmission of Fasciola hepatica in north central Florida (USA). International Journal for Parasitology 20: 695-696.

Christensen, N. O. 1980. A review of the influence of host- and parasite-related factors and environmental conditions on the host-finding capacity of the trematode miracidum. Acta Tropica 37: 303318.

Craig, T. M., and R. R. Bell. 1978. Seasonal transmission of liver flukes to cattle in the Texas Gulf Coast. Journal of the American Veterinary Medical Association 173: 104-107.

Cruz-Mendoza, I., J. A. Figueroa, D. Correa, E. Ramos-Martínez, J. LECUMBERRI-LÓPEZ, AND H. QUIROZ-ROMERO. 2004. Dynamics of
Fasciola hepatica infection in two species of snails in a rural locality of Mexico. Veterinary Parasitology 121: 87-93.

, F. Ibarra-Velarde, E. Naranjo-García, M. T. QuinteroMartíneZ, AND J. LeCuMBerRi-LóPEZ. 2002. Identificación taxonómica, estacionalidad y grado de infección con Fasciola hepatica de moluscos huéspedes y no huéspedes intermediarios del tremátodo en el rancho de la Universidad Autónoma de Hidalgo, en Tulancingo, Hidalgo, México. Veterinaria México 33: 189-200.

- - - M. T. Quintero-Martínez, E. Naranjo-García, J. LeCUMBerRi-LóPez, AND D. CorReA. 2005. Seasonal transmission of Fasciola hepatica in cattle and Lymnaea (Fossaria) humilis snails in central Mexico. Parasitology Research 95: 283-286.

Cruz-Reyes, A. 1986. Ciclo Evolutivo. Fasciolasis. Vol Conmemorativo. Centenario del Descubrimiento del Ciclo de Fasciola hepatica Thomas y Leuchart, 1883, Facultad de Medicina Veterinaria y Zootecnia, UNAM, México, D.F., p. 91-114.

Dalton, J. P., S. O. Neill, C. Stack, P. Collins, A. Walshe, M. Sekiya, S. Doyle, G. Mulcahy, D. Hoyle, E. Khaznadi, N. Moire, G. Brennan, A. Mousley, N. Kreshchenko, A. G. Maule, And S. M. Donnelly. 2003. Fasciola hepatica cathepsin L-like proteases: Biology, function, and potential in the development of first generation liver fluke vaccines. International Journal for Parasitology 33: $1173-1181$.

Dreyfuss, G., AND D. Rondelaud. 1997. Fasciola gigantica and $F$. hepatica: A comparative study of some characteristics of Fasciola infection in Lymnaea truncatula infected by either of the two trematodes. Veterinary Record 28: 123-130.

-, P. Vignoles, D. Rondelaud, and C. Vareille-Morel. 1999. Fasciola hepatica: Characteristics of infection in Lymnaea truncatula in relation to the number of miracidia at exposure. Experimental Parasitology 92: 19-23.

GraczyK, T. K., AND B. Fried. 1999. Development of Fasciola hepatica in the intermediate host. In Fasciolosis, J. P. Dalton (ed.). CABI Publishing, Wallingford, Oxon, U.K., p. 31-46.

Kendall, S. B. 1965. Relationships between the species of Fasciola and their molluscan hosts. Advances in Parasitology 3: 59-99.

Mas-Coma, S., I. R. Funatsu, AND M. D. Bargues. 2001. Fasciola hepatica and lymnaeid snails occurring at very high altitude in South America. Parasitology 123: S115-S127.

Upatham, E. S. 1972. Effects of some physico-chemical factors on the infection of Biomphalaria glabrata (Say) by miracidia of Schistosoma mansoni Sambon in St. Lucia, West Indies. Journal of Helminthology 46: 307-315.

WiLson, R. A. 1969. Fine structure of the tegument of the miracidium of Fasciola hepatica L. Journal of Parasitology 55: 124-138.

American Society of Parasitology. M. A. Cheadle, D. S. Lindsay, and E. C. Greiner (2006). "Lack of Sarcocystis neurona Antibody Response in Virginia Opossums (Didelphis virginiana) Fed Sarcocystis neurona-Infected Muscle Tissue," Journal of Parasitology, Vol. 92, No. 3, pp. 652-654. doi: http://dx.doi.org/10.1645/GE-788R.1

\title{
Lack of Sarcocystis neurona Antibody Response in Virginia Opossums (Didelphis virginiana) Fed Sarcocystis neurona-Infected Muscle Tissue
}

\begin{abstract}
M. A. Cheadle, D. S. Lindsay ${ }^{\star}$, and E. C. Greiner, Department of Pathobiology, College of Veterinary Medicine, University of Florida, P.O. Box 110880, 2015 SW 16th Avenue, Gainesville, Florida 32610-0880; *Center for Molecular Medicine and Infectious Diseases, Department of Biomedical Sciences and Pathobiology, Virginia-Maryland Regional College of Veterinary Medicine, Virginia Tech, 1410 Prices Fork Road, Blacksburg, Virginia 24061-0342. †To whom correspondence should be addressed. e-mail: lindsayd@vt.edu
\end{abstract}

ABSTRACT: Serum was collected from laboratory-reared Virginia opossums (Didelphis virginiana) to determine whether experimentally infected opossums shedding Sarcocystis neurona sporocysts develop serum antibodies to $S$. neurona merozoite antigens. Three opossums were fed muscles from nine-banded armadillos (Dasypus novemcinctus), and 5 were fed muscles from striped skunks (Mephitis mephitis). Serum was also collected from 26 automobile-killed opossums to determine whether antibodies to $S$. neurona were present in these opossums. Serum was analyzed using the $S$. neurona direct agglutination test (SAT). The SAT was modified for use with a filter paper collection system. Antibodies to $S$. neurona were not detected in any of the serum samples from opossums, indicating that infection in the opossum is localized in the small intestine. Antibodies to $S$. neurona were detected in filter-paperprocessed serum samples from 2 armadillos naturally infected with $S$. neurona.

Sarcocystis neurona is a causative agent of the neuromuscular disease equine protozoal myeloencephalitis (EPM) (Dubey et al., 1991; 2001) and has been isolated from horses in North and South America (Dubey 
TABLE I. Results of the Sarcocystis neurona direct agglutination test using serum and blood from Virginia opossums (Didelphis virginiana).

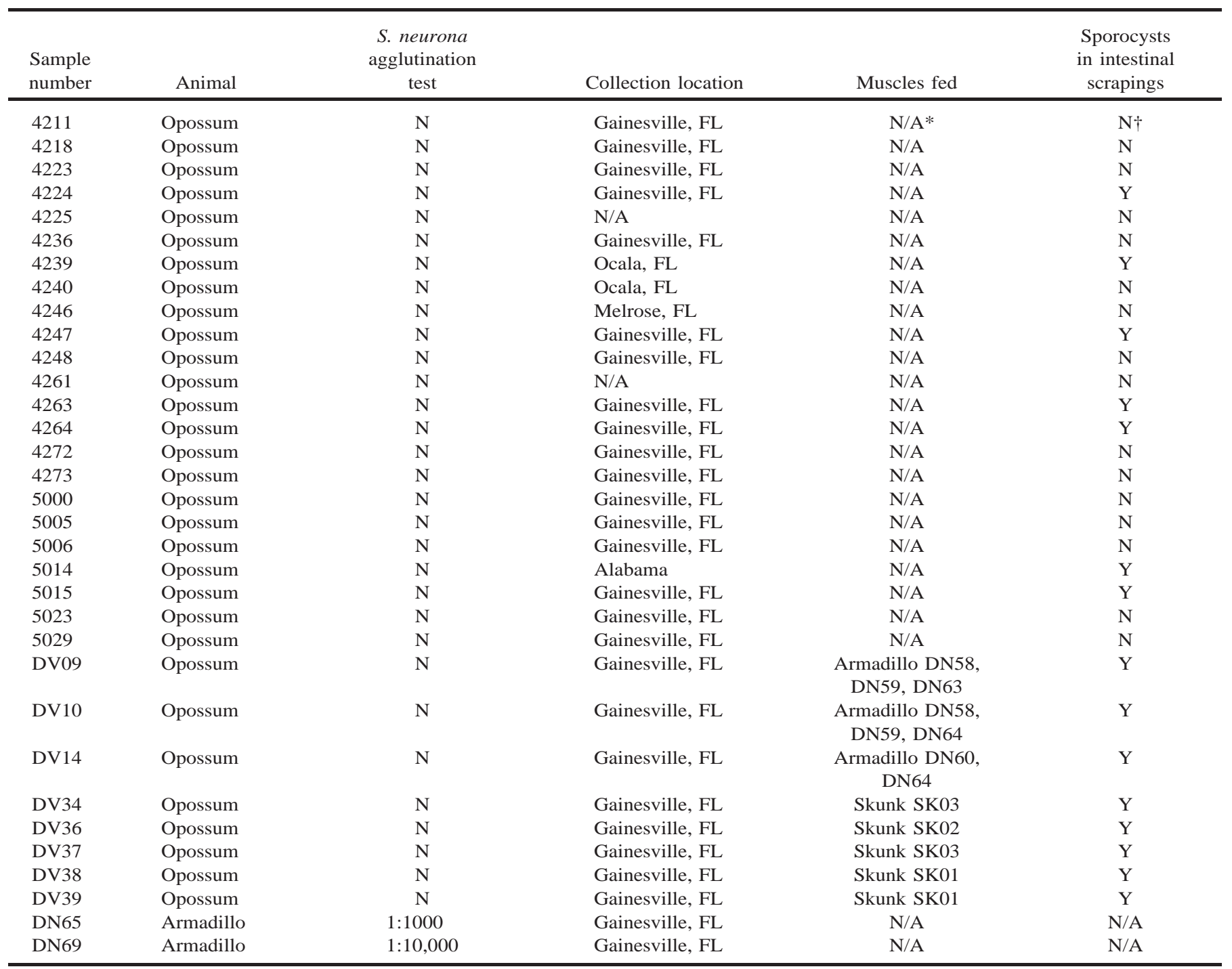

$*$ N/A $=$ not available.

$\dagger \mathrm{N}=$ negative; $\mathrm{Y}=$ positive .

et al., 1991, 2001; Granstrom et al., 1992). The Virginia opossum (Didelphis virginiana) has been identified as a definitive host of $S$. neurona (Fenger et al., 1997; Dubey and Lindsay, 1998; Tanhauser et al., 1999). Two intermediate hosts for $S$. neurona are the nine-banded armadillo (Dasypus novemcinctus) and striped skunk (Mephitis mephitis) (Cheadle, Tanhauser et al., 2001; Cheadle, Yowell, et al., 2001). Cheadle, Yowell et al. (2001) and Tanhauser et al. (2001) have shown that skunks seroconvert to $S$. neurona after experimental infection and that naturally infected, wild-caught armadillos have plasma antibodies to $S$. neurona. No previous studies have documented whether Virginia opossums develop antibodies to $S$. neurona when stages of $S$. neurona are present in their intestines. Mitchell et al. (2002) did not find antibodies to $S$. neurona in 7 opossums from Connecticut; however, they did not examine the intestines of their skunks for sporocysts, so it is unknown whether these potential hosts were infected at the time of sampling. The presence of antibodies to $S$. neurona would allow investigators to determine whether an opossum was infected with $S$. neurona gut stages without scraping the intestine and looking for sporocyst/oocyst stages. In the present study, we examined serum samples from experimentally inoculated Virginia opossums to determine whether opossums experimentally exposed to $S$. neurona develop antibodies to $S$. neurona using a direct agglutination test. We also examined whole blood samples from automobile-killed Virginia opossums to determine whether naturally infected Virginia opossums had antibodies to $S$. neurona.

Serum samples were collected from experimentally infected Virginia opossums (D. virginiana). Three of the opossums had been fed muscle tissue from nine-banded armadillo (D. novemcinctus) naturally infected with Sarcocystis (Cheadle, Tanhauser et al., 2001), and 5 were fed muscle from striped skunks (M. mephitis) experimentally infected with $S$. neurona (Cheadle, Yowell, et al., 2001).

Twenty-six Virginia opossums killed by automobiles were obtained in Alachua County, Florida. The blood from the opossums had coagulated; therefore, a filter-paper method was developed and used. An 11.0$\mathrm{cm}^{2}$ piece of round filter paper was soaked in blood left in the thoracic cavity, absorbing approximately $0.10 \mathrm{ml}$ of blood. The filter paper was labeled and frozen at $-20 \mathrm{C}$ until it was submitted to the Department of Biomedical Sciences and Pathobiology, Virginia Tech, for detection of antibodies via the $S$. neurona direct agglutination test (SAT) (Lindsay and Dubey, 2001). Serum samples from experimentally inoculated opossums were examined as previously described for experimentally infected rodents (Lindsay and Dubey, 2001). Blood samples from automobilekilled opossums were examined using the following modifications of the SAT: briefly, a square $(\sim 16 \mathrm{~mm})$ that was soaked in blood was cut from the larger piece of filter paper. The square was added to $200 \mathrm{ml}$ 
of phosphate-buffered saline (PBS) in a 1.5-ml microfuge tube. The tube was then vortexed for approximately $30 \mathrm{sec}$. The solution stood at $20 \mathrm{C}$ for $15 \mathrm{~min}$, was vortexed again, and the remaining filter paper was removed from the solution. A 1:1 dilution of this solution was used for the SAT. All sera from experimentally infected opossums were examined at a 1:50 dilution, and the examiner was blind as to the source. Sera from mice experimentally infected with $S$. neurona were used as a positive control (1:50 dilution). Negative controls consisted of normal mouse sera (1:50 dilution) and sera from mice experimentally infected with Neospora caninum (1:50 dilution) and Toxoplasma gondii (1:50 dilution).

Filter-paper samples from 2 armadillos (DN65 and DN69) containing $S$. neurona-like sarcocysts and whose muscle tissue induced $S$. neurona sporocyst excretion in opossums (Cheadle, Tanhauser, et al., 2001) were examined in the SAT to determine whether the SAT modification worked in naturally infected animals. Samples from these armadillos were examined at dilutions of 1:10, and serial dilutions were endpoint titrated.

None of the serum samples collected from the experimentally fed opossums was found to contain antibodies to $S$. neurona at a 1:50 dilution using the SAT (Table I). All 3 (100\%) armadillos fed opossums had sporocysts in their intestines (1 identified as $S$. neurona) and 5 of $5(100 \%)$ skunks fed opossums had sporocysts in their intestines (5 identified as $S$. neurona). None of the serum samples collected from automobile-killed opossums was found to contain antibodies to $S$. neu rona at a 1:1 dilution. Seven of $26(30 \%)$ automobile-killed opossums had sporocysts in their intestines. Naturally infected armadillo DN65 had a titer of 1:1,000, and naturally infected armadillo DN69 had a titer of $1: 10,000$ in the SAT.

Unlike an opossum, which developed antibodies to $S$. neurona after parental inoculation with $S$. neurona merozoites (Cheadle, Yowell et al., 2001), none of the opossums in this study developed antibodies to $S$. neurona in their serum, even after $S$. neurona had completed its life cycle in the intestinal tracts. Although it is likely that opossums will seroconvert to other species of Sarcocystis, such as Sarcocystis greineri, where asexual stages are present in extra-intestinal tissues of the opossum intermediate host (Cheadle, 2001), diagnostic tests are not currently available to detect antibodies to that species. Muscle sections were not observed to determine whether sarcocysts of $S$. greineri were present; therefore, it is not known whether antibodies to $S$. greineri were present, or whether they will cross-react with the SAT. Further testing to determine whether the opossums developed antibodies to other species of Sarcocystis that use it as a definitive host were not performed.

The lack of antibody production to $S$. neurona by opossums is probably due to a lack of host immune response to the sexual stages of the parasite in intestinal tissues. It also indicates a lack of migration of asexual stages of $S$. neurona in the opossum. Another reason for the lack of antibody detection may be that the antigen in this test is not recognized by antibodies produced against the sexual stages of the parasite contained in the intestine. The lack of antibody production will not allow the screening of sera using the SAT to determine whether an opossum is infected with $S$. neurona; however, alterations to the test may allow for the detection of antibodies against sexual stages.

Our finding that the filter-paper modification of the SAT is valid has implications in epidemiological studies. This simple method can be used to collect samples in the field for transport back to the laboratory. The filter-paper samples require less space and will not break as will glass test tubes or collection vials. A recent study on beavers using this filterpaper method indicated that $4(6 \%)$ of 62 beavers from Massachusetts had antibodies to $S$. neurona (Jordan et al., 2005).

The authors would like to thank the student assistants who helped with opossum and serum collection and SAT testing. This study was supported in part by a grant from the Florida Pari-Mutual Wagering Trust Fund.

\section{LITERATURE CITED}

Cheadle, M. A. 2001. Sarcocystis greineri n. sp. (Protozoa: Sarcocystidae) in the Virginia opossum (Didelphis virginiana). Journal of Parasitology 87: 1085-1089.

, S. M. Tanhauser, J. B. Dame, D. C. Sellon, M. Hines, P. E. Ginn, R. J. MacKay, AND E. C. Greiner. 2001. The nine-banded armadillo (Dasypus novemcinctus) is an intermediate host for Sarcocystis neurona. International Journal for Parasitology 31: 330335 .

, C. A. Yowell, D. C. Sellon, M. Hines, P. E. Ginn, A. E. Marsh, R. J. MacKay, J. B. Dame, and E. C. Greiner. 2001. The striped skunk (Mephitis mephitis) is an intermediate host for Sarcocystis neurona. International Journal for Parasitology 31: 843849 .

Dubey, J. P., S. W. Davis, C. A. Speer, D. D. Bowman, A. De Lahunta, D. E. Granstrom, M. J. Topper, A. N. Hamir, J. F. Cummings, AND M. M. SuTER. 1991. Sarcocystis neurona n. sp. (Protozoa: Apicomplexa), the etiologic agent of equine protozoal myeloencephalitis. Journal of Parasitology 77: 212-218.

, AND D. S. LINDSAY. 1998. Isolation in immunodeficient mice of Sarcocystis neurona from opossum (Didelphis virginiana) faeces, and its differentiation from Sarcocystis falcatula. International Journal for Parasitology 28: 1823-1828.

, W. J. A. Saville, S. M. Reed, D. E. Granstrom, and C. A. SpeER. 2001. A review of Sarcocystis neurona and equine protozoal myeloencephalitis (EPM). Veterinary Parasitology 95: 89-132.

Fenger, C. K., D. E. Granstrom, A. A. Gajadher, N. M. Williams, S. A. McCrillis, S. Stamper, J. L. Langemeier, and J. P. Dubey. 1997. Experimental induction of equine protozoal myeloencephalitis in horses using Sarcocystis sp. sporocysts from the opossum (Didelphis virginiana). Veterinary Parasitology 68: 199-213.

Granstrom, D. E., O. Alvarez Jr., J. P. Dubey, P. F. Comer, and N. M. Williams. 1992. Equine protozoal myelitis in Panamanian horses and isolation of Sarcocystis neurona. Journal of Parasitology 78: 909-912.

Jordan, C. N., T. Kaur, K. Koenen, S. Destefano, A. M. ZajaC, And D. S. LINDSAY. 2005. Prevalence of agglutinating antibodies to Toxoplasma gondii and Sarcocystis neurona in beavers (Castor canadensis) from Massachusetts. Journal of Parasitology 91: 12281229.

Lindsay, D. S., AND J. P. DuBEy. 2001. Direct agglutination test for the detection of antibodies to Sarcocystis neurona in experimentally infected animals. Veterinary Parasitology 95: 179-186.

Mitchell, S. M., D. J. Richardson, M. A. Cheadle, A. M. ZajaC, AND D. S. LindSAY. 2002. Prevalence of agglutinating antibodies to Sarcocystis neurona in skunks (Mephitis mephitis), raccoons (Procyon lotor), and opossums (Didelphis virginiana) from Connecticut. Journal of Parasitology 88: 1027-1029.

Tanhauser, S. M., C. A. Yowell, T. J. Cutler, E. C. Greiner, R. J. MacKay, AND J. B. DAme. 1999. Multiple DNA markers differentiate Sarcocystis neurona and Sarcocystis falcatula. Journal of Parasitology 85: 221-228.

, M. A. Cheadle, E. T. Massey, B. A. Mayer, D. E. SchroedTer, J. B. Dame, E. C. Greiner, And R. J. MacKay. 2001. The nine-banded armadillo (Dasypus novemcinctus) is naturally infected with Sarcocystis neurona. International Journal for Parasitology 31: 325-329. 